\title{
Findings on the relationship between cardiovascular disease and coronavirus disease 2019: a systematic review
}

\section{Yuri Henrique da Silva1}

Universidade Federal de Pernambuco https://orcid.org/0000-0003-1936-3269

José Gildo de Moura Monteiro Júnior

Universidade de Pernambuco

Rosângela Ferreira Frade de Araújo ( $\nabla$ rfrade@prospecmol.org )

Universidade Federal de Pernambuco https://orcid.org/0000-0002-6501-3182

\section{Systematic Review}

Keywords: Cardiovascular Disease, Novel Coronavirus, SARS-CoV-2, News

Posted Date: October 6th, 2020

DOI: https://doi.org/10.21203/rs.3.rs-84991/v1

License: (c) (1) This work is licensed under a Creative Commons Attribution 4.0 International License.

Read Full License 


\section{Abstract}

Coronavirus disease 2019 (COVID-19) presents as the main cause of death, respiratory and heart failures, especially in the elderly, immunosuppressed, and those with cardiovascular comorbidities. Therefore, a better understanding of these findings is needed. A systematic review was carried out looking for articles published between December 2019 and May 2020 on the MEDLINE / PubMed search platform using the following descriptors: (((()((("cardiovascular disease") OR ("acute myocardial infarction")) OR ("coronary artery disease")) OR ("acute coronary syndrome")) OR ("atherosclerosis")) OR ("cardiac insufficiency")) OR ("pericarditis")) OR ("myocarditis")) AND ("COVID-19")) OR ("SARS-CoV-2")and considering inclusion and exclusion criteria.40\% of patients infected with SARS-CoV-2 had hypertension or other cardiovascular comorbidities, while $27 \%$ presented cardiovascular complications, mainly acute cardiac injury, arrhythmia and heart failure. The hypotheses of involvement of an intense inflammatory response, decreased immunity and greater expression of ACE2 in the heart, associated with more severe heart conditions, were discussed in this study. The increase in cardiac and inflammatory markers was associated with worse clinical outcomes and risk of death, confirming the need to evaluate them since admission to the hospital. The 10 articles analyzed presented as a limitation the small number of patients inserted, to the detriment of the pandemic state. We warned about the need for better clinical management of patients with cardiovascular comorbidities, and the importance of including this group among the first to be immunized, aiming at reducing the number of fatal cases due to infection. Studies with greater coverage are needed for a better comprehension of the topics discussed here.

\section{Introduction}

In 2019 the first cases of a new betacoronavirus were reported, caused by the agent called SARS-CoV-2 [1]. The outbreak of Coronavirus Disease 2019 (COVID-19) started in China, more precisely in Wuhan, Hubei province, and took proportions on a global scale leading the World Health Organization (WHO), on March 11, 2020, to declare a pandemic state [2,3]. The spread of the disease has as its main characteristic the person-to-person transmission which allows its epidemiological picture to evolve daily, having as updated data on June 06, 2020, the global number of cases exceeding 6663 304, and the number of deaths exceeding 392802 [4, 5]. After gene sequencing, it was verified that SARS-CoV2 shares about $79.6 \%$ of the SARS-CoV genome and, the pathogenesis mechanism of both are similar.

Angiotensin-converting enzyme 2 (ACE2) is used as a receptor [6], a protein that has expression in several human organs such as intestine, kidneys, lung and, heart, making them targets susceptible to infection. In the myocardium, besides the ACE2 being strongly expressed in pericytes, the enzyme showed a higher expression in patients with heart failure, contributing to an increase in the probability of adverse prognosis in this group in the case of SARS-CoV-2 contagion [7].

The SARS-CoV-2 infection has taken different forms: asymptomatic; mild to moderate; severe; critical and lead to death [8]. It is observed that, initially, the appearance of non-specific symptoms such as fever, 
cough, myalgia, or fatigue is more common. Studies show that the most present comorbidities in hospitalized patients are diabetes, hypertension, and cardiovascular diseases, the latter two being more frequent in ICU (intensive care units). Moreover, heart failure and acute heart injury are the most reported complications in deceased patients $[9,10,11]$. In this review, we discuss the association between cardiovascular diseases and COVID-19 considering risk factors and main complications found in infected patients.

\section{Methodology}

The study is a systematic review of the literature in search of an updated answer to a central and guiding question: what relationships have been found so far between cardiovascular diseases and COVID-19? The descriptors were organized using the Boolean operators "AND" and "OR" according to the sequence: (((((((("cardiovascular disease") OR ("acute myocardial infarction")) OR ("coronary artery disease")) OR ("acute coronary syndrome")) OR ("atherosclerosis")) OR ("cardiac insufficiency")) OR ("pericarditis")) OR ("myocarditis")) AND ("COVID-19")) OR ("SARS-CoV-2"). The following filters were applied as inclusion criteria: full text, case reports, classical article, clinical study, clinical trial, comparative study, controlled clinical trial, journal article or multicenter study, articles published between January 2019 and May 8, 2020, research with humans, in English, MEDLINE. The exclusion criteria used were: duplicate articles, reviews, meta-analyzes, and those that presented a main theme or methodologies that did not contribute to the study proposal. So, the descriptors together with the Boolean operators were entered on the MEDLINE platform via PubMed, inclusion criteria were selected in the search for eligible articles and, exclusion criteria were observed by reading abstracts and full text.

\section{Results And Discussion}

10 articles were selected using the filters on the PubMed platform and by consensus between two researchers after reading the abstracts or full texts (Figure 1).

Table 1 shows a brief description of the selected articles. A limitation that we can observe in these studies is the small number of patients inserted in the face of a pandemic. Probably, the rapid spread of the virus found the medical scientific community with insufficient tools to deal with the problem more widely. The urgent interest in understanding COVID-19 in several aspects such as comorbidities, complications, transmission, treatment, among others, has accelerated publications, including many preliminary studies. This can be monitored daily by increasing the number of publications available per day on digital platforms since the beginning of the pandemic. Considering the 848 patients of the 10 articles included in this review, it was observed that approximately $40 \%$ of the cases presented cardiovascular comorbidities, while cardiac complications were reported in about $27 \%$ of the patients, being distributed in $17 \%$ of Acute Heart Injury and $10 \%$ of Heart Failure. In study 7 , a retrospective and single-center case series of the 138 COVID-19 patients reported that $16.7 \%$ patients had arrhythmia. We also observed that the male gender was more prevalent, representing $62 \%$ of the patien 


\section{Cardiovascular comorbidities and worse prognosis in COVID-19}

The findings from studies 1, 2, 3, 6, 7, 8, and 9 in table 1 show clinical outcomes (transfer to the ICU, respiratory and cardiac complications, for example, and death) in patients with COVID-19 and history of hypertension or another cardiovascular disease. Considering the studies that presented data, which enabled a joint assessment (comorbidities and cardiovascular complications compared between groups of patients with the better and worse clinical outcome), it can be noted that heart failure, acute cardiac injury, and elevation of the QTcF interval on the electrocardiogram of patients tend to be directly proportional to the presence of cardiovascular comorbidities (Figure 2). These findings reinforce the inclusion of patients with such comorbidities in the risk group for SARS-CoV2 infection.

In study 7 (Table 1), the group of patients who presented NT-proBNP> 88.64pg / $\mathrm{mL}$ had a higher percentage of cardiovascular comorbidities and elevations in other markers of cardiac injury (myoglobin, $\mathrm{CKMB}$, and $\mathrm{Hs}-\mathrm{Tnl}$ ). Mortality in this group was $60 \%$, while in the group of patients with NT-proBNP $<88.64 \mathrm{pg} / \mathrm{mL}$ there was no death. Although NT-proBNP was related to cardiac injury, it was also an independent factor for the risk of in-hospital death, as well as other markers of cardiac injury and hypertension. In study 10 (Table 1), it is observed that among the fatal cases analyzed, the percentage of cardiovascular comorbidities (hypertension and other heart diseases such as myocardial infarction) was $8 \%$ more in the group of people over 70 years of age and the increase in mortality was mainly related to males in this age group. However, the main symptoms, biochemical tests, and complications that led patients to death were not detailed.

The ACE2 is an aminopeptidase bound to the cell membrane that is involved in cardiac function and the development of hypertension. This enzyme also functions as a receptor for entry into the cell for both SARS-CoV and SARS-CoV-2 [2]. The expression of ACE2 in human cardiac tissues was evaluated and it was noted that those obtained from patients with muscle heart disease showed greater expression of the enzyme, indicating in this group of patients a greater vulnerability to SARS-CoV-2 infection, which may develop lesions, more severe cardiac conditions, and contribute to a worse prognosis [7]. However, it is still unclear in the literature whether hypertensive patients with COVID-19 and treatment with an ACE inhibitor or angiotensin receptor blocker can contribute to an increase in ACE2 and consequently lead to an increased risk of infection in the myocardium by SARS-CoV-2 [2]. Despite that, it has been recommended that these patients should continue treatment unless a change in therapy is made on medical advice [20].

Another point to be considered is that hypertensive patients have high levels of plasminogen, which increases the ability of many viruses to bind to ACE2. The envelope proteins in SARS-CoV-2 are cleaved by furin-like intracellular proteases and this increases the ability of viruses to enter host cells. A type of non-furin cleavage can be exerted by plasmin, generated through plasminogen cleavage. However, despite the participation of plasmin in the entry of various viruses into cells, further in vivo studies are needed to prove this participation concerning SARS-CoV-2 [21]. 


\section{Cardiac markers and prognosis}

The studies from 1 to 4, 6 to 9 of Table 1 presented laboratory findings, among which some markers stand out, such as hypersensitive cardiac troponin I (hs-cTnl); Creatine Kinase MB (CK-MB); Creatine Kinase (CK); B-type Natriuretic Peptide (NT-proBNP); Lactate Dehydrogenase (LDH); High Sensitivity Reactive C Protein (hsCRP) and Myoglobin (MYO). It is observed that these markers were higher in the group of patients who presented more severe cases or who died as a result of infection, than in groups of moderate or recovered cases, thus showing the correlation of the high level of these markers with poor prognosis. It is also observed that cardiac markers had higher levels in elderly patients [16].

It is worth noting that advanced age is associated with the risk of death of patients infected by SARSCoV-2, and in this age group, among the main comorbidities are hypertension and coronary heart disease [11]. Age-related dysfunctions also reverberate in the T-cell function, making it difficult to recognize new antigens and making the elderly more susceptible to infections. Additionally, an increase in the expression of pro-inflammatory cytokines is also observed in this group [22]. Both contribute negatively to the control of the replication of the coronavirus, besides prolonging the inflammatory response that demonstrates to be one of the main causes of the severity of COVID-19, that is, the cytokine storm is part of the pathological process of infection $[9,11]$.

The studies 2 and 7 (Table 1) demonstrate that the levels of inflammatory markers such as hsCRP and Procalcitonin (PCT) are higher in critically ill or deceased patients compared to the group of recovered patients, as well as markers of cardiac injury - hs-cTnl, NT-proBNP, MYO, and CK-MB are also there. These findings indicate a possible association between inflammation and cardiac injury in COVID-19. Linked to this, as patients with cardiac comorbidities present a greater expression of ACE2 [7], this may favor the mechanism of direct injury to the cardiac tissue, caused by the toxicity induced by the virus [23].

In studies 7 and 9 (Table 1), the cardiac markers hs-cTnl, CK-MB, MYO, LDH, and NT-proBNP were associated with mortality. Already in study 8 (Table 1) an association was also found between changes in hs-cTnl levels and the risk of death, with a rapid increase in its concentration after the 16th day of the disease being observed in deceased patients, as well as being present in more than half of them. The trials with hs-cTnl are effective in the diagnosis of Acute Coronary Syndrome (ACS), and its use allows a more precise report in the indication of myocardial injury. However, despite the alteration of the levels of this enzyme to predict suspicion of ACS, it was observed in patients with COVID-19 without heart symptoms, even though its elevation is more common after the onset of symptoms [24]. This raises the possibility of secondary cardiac injury related to an increase in oxygen demand caused by sepsis in subclinical coronary artery disease. Sepsis would lead to ischemia resulting in type 2 acute myocardial infarction [25]. This sequence of events may contribute to the elucidation of the findings of study 3 (Table 1), which included 113 patients who died as a result of the COVID-19, among which $100 \%$ had sepsis and $49 \%$ had heart failure. The same study points to higher levels of hs-cTnl, NT-proBNP, and LDH in deceased 
patients compared to survivors. In study 9 (Table 1), the values of these markers, including the CKMB, were also higher at the admission of non-survivors.

Interestingly, study 4 (Table 1) found changes in the concentration of CK-MB in $66.7 \%$ of children and $14.3 \%$ of adults. None of the children required intensive treatment or presented serious complications, although the increase in CKMB indicates cardiac injury. This finding can be explained by the fact that the ACE2 enzyme is less expressed in children, which can lead to a milder course of the disease [26]. Myocardium seems to be a target of infection also in children [27], but further studies on the effect of SARS-CoV-2 infection on the child's cardiovascular system are necessary. In study 7 (Table 1) the NTproBNP was an independent factor of risk of death in severe cases of infection, although it correlates with the other markers of acute myocardial injury and inflammatory markers. The elevation of cardiac markers seems to represent an adverse prognosis for the SARS-CoV2 patient, evidencing the need for their laboratory request since the patient's admission, aiming at the most appropriate clinical management.

\section{Cardiac complications in COVID-19}

After an average incubation period of approximately 4 to 5 days, the symptoms begin to appear and COVID-19 tends to last for two weeks with worsening in the second week due to the inflammatory response that follows the virus's replication period. In this short time, the most severe complications of the disease can happen [28]. Acute cardiac injury and heart failure were the main cardiovascular complications found in patients infected with SARS-CoV-2 among studies selected for this review (Figure 2). In addition to the involvement of ACE2, which possibly can contribute to increasing the risk of cardiac complications in COVID-19, especially in the presence of cardiovascular comorbidities, as previously described, other hypotheses have been discussed, such as those mentioned by Adão and Guzik [29]. The highlight was given to inflammatory cytokines and hypoxia generated by the impairment of the respiratory system in COVID-19.

The rapid replication of the virus can cause massive death of epithelial and endothelial cells, and vascular leakage, triggering the exuberant production of pro-inflammatory cytokines and chemokines [30]. In studies 1, 2, 7 and 8 (Table 1), higher levels of inflammatory markers were found (IL-6, IL-10, and TNF-a; IL-6, IL-18, IL-10, IL-2, and TNF-a receptors; PCR; ferritin, and IL-6, respectively) in the group of patients with more severe cases of the disease. TNF-a, IL-1, IL-6, IL-8, IL-12, IL-18, and interferon-gamma (IFNY) are pro-inflammatory cytokines, which act as mediators of the immune system. Anti-inflammatory cytokines, such as interleukins $4,5,10,11$, and 13 , are also produced and the regulation of this balance is complex. The pro-inflammatory cytokines effectively initiate the inflammatory process against infectious agents. TNF- $a, I L-1, I L-6$ are responsible for raising protein levels in the acute inflammatory phase, which includes C-reactive protein (CRP) during infection [31, 32]. 
When a set of cytokines is considered, the predictive value for cardiac complications increases, since it is known that cytokines work together leading to a complex inflammatory response [33]. IL-6 participates in the activation of $\mathrm{T}$ lymphocytes and the cytotoxicity of these cells leads to an intense inflammatory response that can damage the heart muscle [34]. The T-lymphocytes present a cardiotropism by an interaction between the heart-produced hepatocyte growth factor (HGF) and c-Met, the HGF receptor on naïve T-cells [35]. Also, clinical trials showed that both TNF- $a$ and IL-1 are associated with impaired systolic and diastolic function and, also leading to adverse cardiac remodeling and decreased contractility of the heart muscle due to a reduction in oxygen consumption of the respiratory chain [36, 37, 38, 39]. The 77-year-old man (with obesity and a history of hypertension) in study 5 (Table 1) had an acute ischemic injury (coronary artery atherosclerosis), but no evidence of myocarditis was found. So, in patients in whom heart failure is caused by inflammatory mechanisms, there is an expectation that welltargeted anti-inflammatory therapies can be used to obtain a better clinical outcome for patients [40].

One of the therapeutic options being analyzed for COVID-19 are chloroquine (CQ) and hydroxychloroquine (HCQ), antimalarial drugs and also used in treating some chronic rheumatic condictions due to immunomodulatory properties, for example, the inhibition of the production of proinflammatory cytokines such as IL-1, IL-6 and TNF-a [41, 42, 43]. Although CQ has antiviral properties tested in vitro, it has not always been confirmed during the treatment of patients with viral infections and the mechanisms of action of this drug may vary according to the pathogen. Among these mechanisms stand out the alkalinization of endosomes affecting the proper maturation of the viral protein and the recognition of the viral antigen by dendritic cells. This recognition occurs through a pathway that involves the Toll-like receptor that requires endosomal acidification. And finally, QC showed an anti-SARS-CoV-1 effect in vitro, decreasing the glycosylation of ACE2 [43, 44].

In study 6 (Figure 2), which included patients in severe COVID-19, was observed that the group of patients who received higher doses of QC had a higher percentage of acute cardiac injury, but it should be taken into account that this group also presented a higher percentage of cardiovascular comorbidities and a higher mean age. Added to this, the group that received high doses of QC (ie, 600mg twice daily for 10 days) presented more instance of QTc interval greater than 500 milliseconds compared with the lowdosage group (ie, $450 \mathrm{mg}$ twice daily on day 1 and once daily for 4 days). Therefore, suggesting that the QC should be administered with caution, especially in severe cases of the infection. At doses beyond the safety margin, chloroquine can show pro-arrhythmic activity mainly because of its ability to inhibit the cardiac potassium current from the internal rectifier and, consequently, induce lethal ventricular arrhythmias [45].

\section{Conclusion}

The presence of cardiovascular comorbidity points to an increased risk of complications in COVID-19, such as heart failure and acute cardiac injury. Besides, higher levels of inflammatory and cardiac markers were associated with a worse prognosis of infected patients. These findings seem to support the hypothesis that the probable higher expression of ACE2 in the heart of patients with such comorbidities 
allows greater entry of the virus into the cell, an intense inflammatory response that leads to decreased oxygen consumption and less contractibility. However, it is important to note that the studies discussed in this systematic review, included a small number of infected patients, considering a pandemic. These studies reinforce the need for attention to the group of cardiac patients, both for better clinical management and for new studies, given the poor prognosis that the infection promotes to these patients. We emphasize the importance of including this group among those who will receive the first doses of immunization, certainly contributing to a decrease in fatal cases due to SARS-CoV-2.

\section{Declarations}

\section{Acknowledgment}

Everyone who has been working on the front lines in defense of life during this pandemic.

\section{Funding}

None

\section{Conflicts of interest/Competing interests}

None

\section{Ethics approval}

Not applicable

\section{Consent to participate}

Not applicable

\section{Consent for publication}

All authors agree with the publication

\section{Availability of data and material}

The datasets generated during and/or analyzed during the current study are available from the corresponding author on reasonable request. 


\section{Code availability}

Not applicable

\section{Authors' contributions}

Conceptualization: Rosângela Ferreira Frade de Araújo; Methodology: Rosângela ferreira Frade de Araújo, Yuri Henrique da Silva; Formal analysis and investigation: Rosângela ferreira Frade de Araújo, Yuri Henrique da Silva; Writing - original draft preparation: Yuri Henrique da Silva; Writing - review and editing: Rosângela Ferreira Frade de Araújo, José Gildo de Moura Monteiro Júnior.

\section{References}

[1] Lake MA. What we know so far: COVID-19 current clinical knowledge and research. Clin Med (Lond). 2020;20(2):124-127. htpps://doi.org/10.7861/clinmed.2019-coron

[2] Zheng YY, Ma YT, Zhang JY, Xie X. COVID-19 and the cardiovascular system. Nat Rev Cardiol. 2020;17(5):259-260. htpps://doi.org/10.1038/s41569-020-0360-5

[3] World Health Organization. WHO Director-General's opening remarks at the media briefing on COVID19 - 11 March 2020. 2020. http://www.who.int/dg/speeches/detail/who-director-general-s-openingremarks-at-the-media-briefing-on-covid-19-11-march-2020. Accessed on May 21, 2020.

[4] Chan JF, Yuan S, Kok KH, et al. A familial cluster of pneumonia associated with the 2019 novel coronavirus indicating person-to-person transmission: a study of a family cluster. Lancet. 2020;395(10223):514-523. htpps://doi.org/10.1016/S0140-6736(20)30154-9

[5] World Health Organization. Situation Report - 121. Data as received by WHO from national authorities by 10:00 CEST, 20 May 2020. 2020. http://www.who.int/docs/default-source/coronaviruse/situationreports/20200520-covid-19-sitrep-121.pdf?sfvrsn=c4be2ec6_2 . Accessed on May 21, 2020.

[6] Zhou P, Yang XL, Wang XG, et al. A pneumonia outbreak associated with a new coronavirus of probable bat origin. Nature. 2020;579(7798):270-273. htpps://doi.org/10.1038/s41586-020-2012-7

[7] Chen L, Li X, Chen M, Feng Y, Xiong C. The ACE2 expression in human heart indicates new potential mechanism of heart injury among patients infected with SARS-CoV-2. Cardiovasc Res. 2020;116(6):10971100. htpps://doi.org/10.1093/cvr/cvaa078

[8] Epidemiology Working Group for NCIP Epidemic Response, Chinese Center for Disease Control and Prevention. Zhonghua Liu Xing Bing Xue Za Zhi. 2020;41(2):145-151.

htpps://doi.org/10.3760/cma.j.issn.0254-6450.2020.02.003 
[9] Chen G, Wu D, Guo W, et al. Clinical and immunological features of severe and moderate coronavirus disease 2019. J Clin Invest. 2020;130(5):2620-2629. htpps://doi.org/10.1172/JCl137244

[10] Chen $T$, Wu D, Chen $\mathrm{H}$, et al. Clinical characteristics of 113 deceased patients with coronavirus disease 2019: retrospective study [published correction appears in BMJ. 2020 Mar 31;368:m1295]. BMJ. 2020;368:m1091. htpps://doi.org/10.1136/bmj.m1091

[11] Zhou F, Yu T, Du R, et al. Clinical course and risk factors for mortality of adult inpatients with COVID19 in Wuhan, China: a retrospective cohort study [published correction appears in Lancet. 2020 Mar 28;395(10229):1038]. Lancet. 2020;395(10229):1054-1062. htpps://doi.org/10.1016/S01406736(20)30566-3

[12] Huang C, Wang Y, Li X, et al. Clinical features of patients infected with 2019 novel coronavirus in Wuhan, China [published correction appears in Lancet]. Lancet. 2020;395(10223):497-506. htpps://doi.org/10.1016/S0140-6736(20)30183-5

[13] Su L, Ma X, Yu H, et al. The different clinical characteristics of corona virus disease cases between children and their families in China - the character of children with COVID-19. Emerg Microbes Infect. 2020;9(1):707-713. htpps://doi.org/10.1080/22221751.2020.1744483

[14] Barton LM, Duval EJ, Stroberg E, Ghosh S, Mukhopadhyay S. COVID-19 Autopsies, Oklahoma, USA. Am J Clin Pathol. 2020;153(6):725-733. htpps://doi.org/10.1093/ajcp/aqaa062

[15] Borba MGS, Val FFA, Sampaio VS, et al. Effect of High vs Low Doses of Chloroquine Diphosphate as Adjunctive Therapy for Patients Hospitalized With Severe Acute Respiratory Syndrome Coronavirus 2 (SARS-CoV-2) Infection: A Randomized Clinical Trial. JAMA Netw Open. 2020;3(4):e208857. Published 2020 Apr 24. htpps://doi.org/10.1001/jamanetworkopen.2020.8857

[16] Gao L, Jiang D, Wen XS, et al. Prognostic value of NT-proBNP in patients with severe COVID19. Respir Res. 2020;21(1):83. Published 2020 Apr 15. htpps://doi.org/10.1186/s12931-020-01352-w

[17] Wang D, Yin Y, Hu C, et al. Clinical course and outcome of 107 patients infected with the novel coronavirus, SARS-CoV-2, discharged from two hospitals in Wuhan, China. Crit Care. 2020;24(1):188. Published 2020 Apr 30. htpps://doi.org/10.1186/s13054-020-02895-6

[18] Korean Society of Infectious Diseases and Korea Centers for Disease Control and Prevention. Analysis on 54 Mortality Cases of Coronavirus Disease 2019 in the Republic of Korea from January 19 to March 10, 2020. J Korean Med Sci. 2020;35(12):e132. Published 2020 Mar 30.

htpps://doi.org/10.3346/jkms.2020.35.e132

[19] National Health Commission of the People's Republic of China. Guidelines for Diagnosis and Treatment Protocol for Novel Coronavirus Pneumonia, Trial Version 7 by National Health Commission of China. 2020. http://en.nhc.gov.cn/2020-03/29/c_78469.htm . Accessed on June 03, 2020. 
[20] Statement from the American Heart Association, the Heart Failure Society of America, and the American College of Cardiology. Patients taking ACE-i and ARBs who contract COVID-19 should continue treatment, unless otherwise advised by their physician [press release]. heart.org, March 17, 2020.ஐ2020. https://newsroom. heart.org/news/patients-taking-ace-i-and-arbs-who-contract-covid-19-should-continuetreatment-unless-otherwise-advised-by-their-physician . Accessed on June 3, 2020.

[21] Ji HL, Zhao R, Matalon S, Matthay MA. Elevated Plasmin(ogen) as a Common Risk Factor for COVID19 Susceptibility. Physiol Rev. 2020;100(3):1065-1075. htpps://doi.org/10.1152/physrev.00013.2020

[22] ALVES AS, BUENO V. Imunosenescência: participação de linfócitos T e células mieloides supressoras nas alterações da resposta imune relacionadas ao envelhecimento. Einstein (São Paulo) [online]. 2019, vol.17 https://doi.org/10.31744/einstein_journal/2019rb4733.

[23] Zhu H, Rhee JW, Cheng P, et al. Cardiovascular Complications in Patients with COVID-19: Consequences of Viral Toxicities and Host Immune Response [published correction appears in Curr Cardiol Rep. 2020 May 13;22(5):36]. Curr Cardiol Rep. 2020;22(5):32. Published 2020 Apr 21. htpps://doi.org/10.1007/s11886-020-01292-3

[24] Vasile VC, Jaffe AS. High-Sensitivity Cardiac Troponin for the Diagnosis of Patients with Acute Coronary Syndromes. Curr Cardiol Rep. 2017;19(10):92. Published 2017 Aug 24.

htpps://doi.org/10.1007/s11886-017-0904-4

[25] Siripanthong B, Nazarian S, Muser D, et al. Recognizing COVID-19-related myocarditis: the possible pathophysiology and proposed guideline for diagnosis and management [published online ahead of print, 2020 May 5]. Heart Rhythm. 2020;\$1547-5271(20)30422-7.

htpps://doi.org/10.1016/j.hrthm.2020.05.001

[26] Ludvigsson JF. Systematic review of COVID-19 in children shows milder cases and a better prognosis than adults. Acta Paediatr. 2020;109(6):1088-1095. htpps://doi.org/10.1111/apa.15270

[27] Sanna G, Serrau G, Bassareo PP, Neroni P, Fanos V, Marcialis MA. Children's heart and COVID-19: Upto-date evidence in the form of a systematic review [published online ahead of print, 2020 May 30]. Eur J Pediatr. 2020;1-9. htpps://doi.org/10.1007/s00431-020-03699-0

[28] Sartor Z, Hess B. Increasing the Signal-to-Noise Ratio: COVID-19 Clinical Synopsis for Outpatient Providers. J Prim Care Community Health. 2020;11:2150132720922957.

htpps://doi.org/10.1177/2150132720922957

[29] Adão R, Guzik TJ. Inside the heart of COVID-19. Cardiovasc Res. 2020;116(6):e59-e61. htpps://doi.org/10.1093/cvr/cvaa086

[30] Yang, Ming, Cell Pyroptosis, a Potential Pathogenic Mechanism of 2019-nCoV Infection (January 29, 2020). htpps://doi.org/10.2139/ssrn.3527420 
[31] PENG, Y.; YUAN, Z.; LI, H. Removal of inflammatory cytokines and endotoxin by veno-venous continuous renal replacement therapy for burned patients with sepsis. Burns, 31(5): 623-628, 2005. htpps://doi.org/10.1016/j.burns.2005.02.004

[32] SCHULTE, W.; BERNHAGEN, J.; BUCALA, R. Cytokines in sepsis: potent immunoregulators and potential therapeutic targets-an updated view. Mediators of inflammation, v. 2013, 2013. doi: htpps://doi.org/10.1155/2013/165974

[33] Kristono GA, Holley AS, Lakshman P, Brunton-O'Sullivan MM, Harding SA, Larsen PD. Association between inflammatory cytokines and long-term adverse outcomes in acute coronary syndromes: A systematic review. Heliyon. 2020;6(4):e03704. Published 2020 Apr 7. htpps://doi.org/10.1016/j.heliyon.2020.e03704

[34] Siripanthong B, Nazarian S, Muser D, et al. Recognizing COVID-19-related myocarditis: the possible pathophysiology and proposed guideline for diagnosis and management. Heart Rhythm. 2020;S15475271(20)30422-7. htpps://doi.org/10.1016/j.hrthm.2020.05.001

[35] Komarowska I, Coe D, Wang G, et al. Hepatocyte Growth Factor Receptor c-Met Instructs T Cell Cardiotropism and Promotes T Cell Migration to the Heart via Autocrine Chemokine Release. Immunity. 2015;42(6):1087-1099. htpps://doi.org/10.1016/j.immuni.2015.05.014

[36] Bozkurt B, Kribbs SB, Clubb FJ Jr, et al. Pathophysiologically relevant concentrations of tumor necrosis factor-alpha promote progressive left ventricular dysfunction and remodeling in rats. Circulation. 1998;97(14):1382-1391. htpps://doi.org/10.1161/01.cir.97.14.1382

[37] Van Tassell BW, Toldo S, Mezzaroma E, Abbate A. Targeting interleukin-1 in heart disease. Circulation 2013;128:1910-23. htpps://doi.org/10.1161/CIRCULATIONAHA.113.003199

[38] Van Tassell BW, Seropian IM, Toldo S, Mezzaroma E, Abbate A. Interleukin-1 $\beta$ induces a reversible cardiomyopathy in the mouse. Inflamm Res. 2013;62(7):637-640. htpps://doi.org/10.1007/s00011-0130625-0

[39] Zell R, Geck P, Werdan K, Boekstegers P. TNF-alpha and IL-1 alpha inhibit both pyruvate dehydrogenase activity and mitochondrial function in cardiomyocytes: evidence for primary impairment of mitochondrial function. Mol Cell Biochem. 1997;177(1-2):61-67.

htpps://doi.org/10.1023/a:1006896832582

[40] Murphy SP, Kakkar R, McCarthy CP, Januzzi JL Jr. Inflammation in Heart Failure: JACC State-of-theArt Review. J Am Coll Cardiol. 2020;75(11):1324-1340. htpps://doi.org/10.1016/j.jacc.2020.01.014

[41] Gao J,Tian Z,Yang X. Breakthrough: Chloroquine phosphate has shown apparent efficacy in treatment of COVID-19 associated pneumonia in clinical studies. Biosci Trends. 2020;14(1):72-73. htpps://doi.org/10.5582/bst.2020.01047 
[42] Gautret P, Lagier J-C, Parola P, et al. Hydroxychloroquine and azithromycin as a treatment of COVID19: results of an open-label non-randomized clinical trial. Int J Antimicrob Agents. 2020:105949. htpps://doi.org/10.1016/j.ijantimicag. 2020.105949

[43] Devaux CA, Rolain JM, Colson P, Raoult D. New insights on the antiviral effects of chloroquine against coronavirus: what to expect for COVID-19?. Int J Antimicrob Agents. 2020;55(5):105938. htpps://doi.org/10.1016/j.jjantimicag.2020.105938

[44] Vincent MJ, Bergeron E, Benjannet S, et al. Chloroquine is a potent inhibitor of SARS coronavirus infection and spread. Virol J. 2005;2:69. htpps://doi.org/10.1186/1743-422X-2-69

[45] Crumb WJ Jr, Vicente J, Johannesen L, Strauss DG. An evaluation of 30 clinical drugs against the comprehensive in vitro proarrhythmia assay (CiPA) proposed ion channel panel. J Pharmacol Toxicol Methods. 2016;81:251-262. htpps://doi.org/10.1016/j.vascn.2016.03.

\section{Tables}

Table. 1 Description of selected articles

\section{Figures}

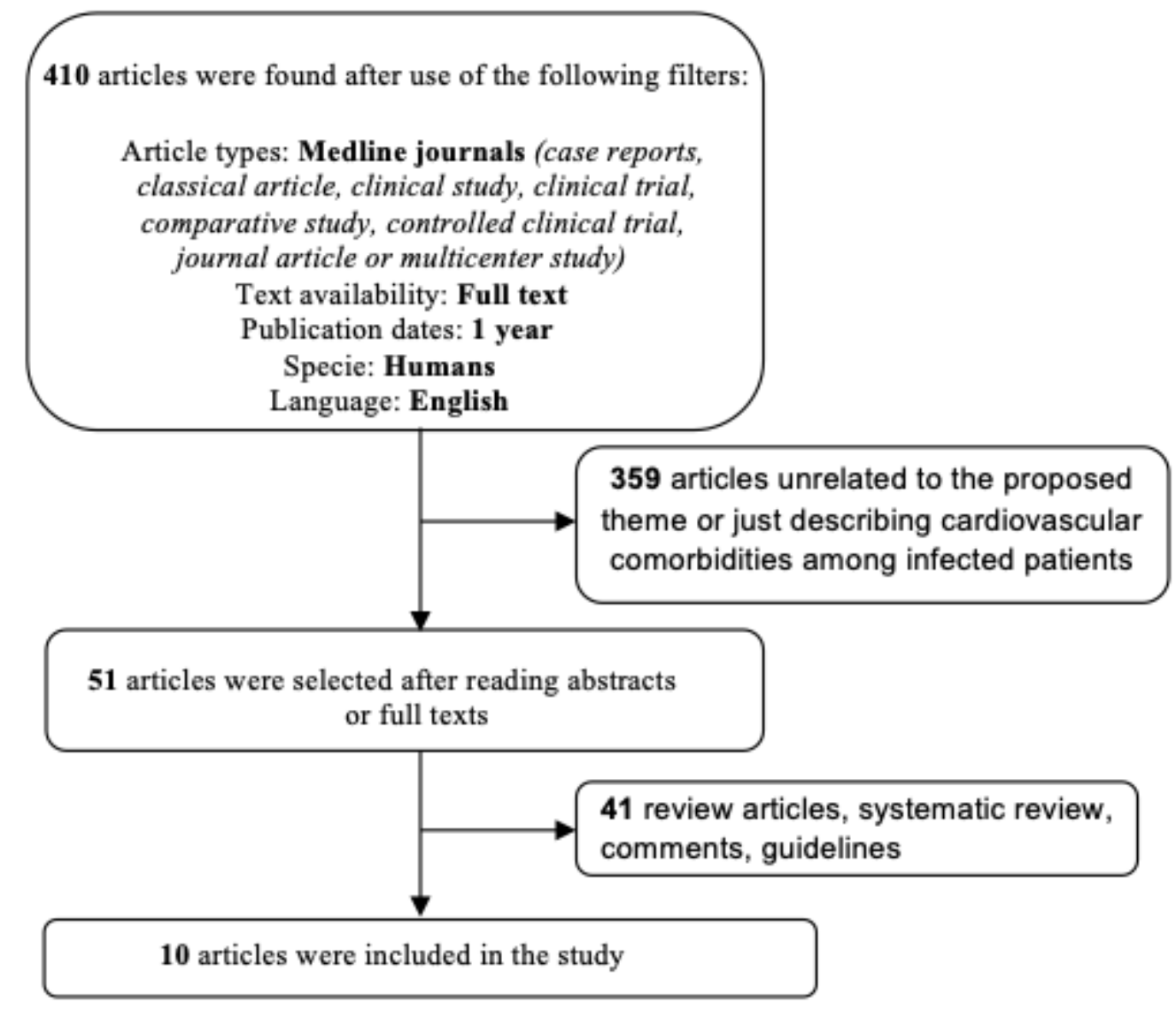




\begin{tabular}{|c|c|c|c|c|}
\hline $\begin{array}{c}\text { Our numbering. } \\
\text { Authors, Year of } \\
\text { publication, Journal }\end{array}$ & Country & Article title & $\begin{array}{l}\text { Patients } \\
\text { included } \\
\text { / Sex }\end{array}$ & $\begin{array}{c}\text { Average } \\
\text { ages }\end{array}$ \\
\hline $\begin{array}{l}\text { 1. Chen et al., } 2020 \text { [9] } \\
\text { The Journal of Clinical } \\
\text { Investigation }\end{array}$ & China & $\begin{array}{c}\text { Clinical and } \\
\text { immunological } \\
\text { features of severe } \\
\text { and moderate } \\
\text { coronavirus disease } \\
2019 .\end{array}$ & $\begin{array}{c}21 / 17 \\
\text { male }\end{array}$ & $\begin{array}{c}61 \\
\text { years } \\
\text { (severe } \\
\text { cases) } \\
52 \text { years } \\
\text { (moderate } \\
\text { cases) }\end{array}$ \\
\hline
\end{tabular}

Main findings and conclusion
related to cardiovascular diseases

Hypertension was comorbidity found in $36.4 \%$ of severe cases and $10 \%$ of moderate cases. $100 \%$ of severe cases

(mortality of $36.4 \%$ ) had acute respiratory distress syndrome and $83.3 \%$ respiratory failure. Secondary infection (27.3\%), acute cardiac injury

(9.1\%), hypoxic encephalopathy (18.2\%), acute kidney injury (18.2\%), shock $(9.1 \%)$, and acute liver injury (9.1\%) were the least frequent findings in these cases.

\begin{tabular}{|c|c|c|c|c|c|}
\hline $\begin{array}{l}\text { 2. Chen et al., } \\
2020 \text { [10] } \\
B M J\end{array}$ & China & $\begin{array}{c}\text { Clinical } \\
\text { characteristics of } \\
113 \text { deceased } \\
\text { patients with } \\
\text { coronavirus disease } \\
\text { 2019: retrospective } \\
\text { study. }\end{array}$ & $\begin{array}{c}274 / 171 \\
\text { male }\end{array}$ & $\begin{array}{l}68 \text { years } \\
\text { (deceased } \\
\text { patients) } \square \\
51 \text { years } \\
\text { (recovered } \\
\text { patients) }\end{array}$ & $\begin{array}{l}\text { Hypertension and cardiovascular } \\
\text { disease were found in } 48 \% \text { and } 14 \% \text { of } \\
\text { severe cases and } 24 \% \text { and } 4 \% \text { of } \\
\text { moderate cases, respectively. The most } \\
\text { frequent complications in patients who } \\
\text { died were: acute respiratory distress } \\
\text { syndrome }(113 ; 100 \%) \text {, type I } \\
\text { respiratory failure }(18 / 35 ; 51 \%) \text {, sepsis } \\
(113 ; 100 \%) \text {, acute cardiac injury } \\
\text { (72/94; } 77 \%) \text {, heart failure }(41 / 83 \text {; } \\
49 \%) \text {, alkalosis }(14 / 35 ; 40 \%) \text {, } \\
\text { hyperkalaemia ( } 42 ; 37 \%) \text {, acute kidney } \\
\text { injury (28; } 25 \%) \text { and hypoxic } \\
\text { encephalopathy (23; } 20 \%) \text {. Cardiac } \\
\text { complications were more found in } \\
\text { patients with cardiovascular } \\
\text { comorbidities. }\end{array}$ \\
\hline $\begin{array}{l}\text { 3. Huang et al., } 2020 \\
\text { [12] } \\
\text { Lancet }\end{array}$ & China & $\begin{array}{l}\text { Clinical features of } \\
\text { patients infected } \\
\text { with } 2019 \text { novel } \\
\text { coronavirus in } \\
\text { Wuhan, China. }\end{array}$ & $\begin{array}{c}11 / 30 \\
\text { male }\end{array}$ & 49 years & $\begin{array}{c}\text { Hypertension and cardiovascular } \\
\text { disease were comorbidities found in } \\
15 \% \text { and } 23 \% \text { of patients in the ICU and } \\
14 \% \text { and } 11 \% \text { of the cases without ICU } \\
\text { care, respectively. The main } \\
\text { complications presented by the patients } \\
\text { were: acute respiratory distress } \\
\text { syndrome (29\%), acute cardiac injury } \\
\text { (12\%; among this } 31 \% \text { of patients in } \\
\text { the ICU and } 4 \% \text { of the cases without } \\
\text { ICU care), and secondary infection } \\
(10 \%) \text {. }\end{array}$ \\
\hline $\begin{array}{l}\text { 4. Su et al., } 2020 \text { [13] } \\
\text { Emerging Microbes \& } \\
\text { Infections }\end{array}$ & China & $\begin{array}{l}\text { The different clinical } \\
\text { characteristics of } \\
\text { coronavirus disease } \\
\text { cases between } \\
\text { children and their } \\
\text { families in China - } \\
\text { the character of } \\
\text { children with } \\
\text { COVID-19. }\end{array}$ & $\begin{array}{c}\text { 23: } 9 \\
\text { children/ } \\
3 \text { male } \\
\text { and } \\
14 \\
\text { adults / } 8 \\
\text { male }\end{array}$ & $\begin{array}{l}\text { Children: } \\
4.5 \text { years } \\
\text { Adults: } \\
42.9 \text { years }\end{array}$ & $\begin{array}{c}6 \text { children and } 4 \text { adults had no } \\
\text { symptoms e no child needed intensive } \\
\text { care. An increase in CK-MB occurred in } \\
66.7 \% \text { of children and only in } 14.3 \% \text { of } \\
\text { adults. }\end{array}$ \\
\hline
\end{tabular}


[14]

American Journal of Clinical Pathology
Oklahoma, USA.

cardiovascular system of a 77-year-old man

(with obesity and history of

hypertension) was an acute ischemic

injury (coronary artery atherosclerosis) but without myocarditis. 42-year-old Man also was found coronary artery disease, mild and aorta intimal fatty streaking but without acute ischemic injury. Died with COVID-19, not from COVID- 19

\begin{tabular}{|c|c|c|c|c|c|}
\hline $\begin{array}{c}\text { 6. Borba et al., } 2020 \\
\text { [15] } \\
\text { JAMA Network Open }\end{array}$ & Brazil & $\begin{array}{l}\text { Effect of High vs } \\
\text { Low Doses of } \\
\text { Chloroquine } \\
\text { Diphosphate as } \\
\text { Adjunctive Therapy } \\
\text { for Patients } \\
\text { Hospitalized With } \\
\text { Severe Acute } \\
\text { Respiratory } \\
\text { Syndrome } \\
\text { Coronavirus 2 } \\
\text { (SARS-CoV-2) } \\
\text { Infection: A } \\
\text { Randomized Clinical } \\
\text { Trial. } \\
\end{array}$ & $\begin{array}{c}81 \text { / } 61 \\
\text { male }\end{array}$ & 51.1 years & $\begin{array}{l}37 \% \text { of patients who received low doses } \\
\text { of chloroquine and } 53.6 \% \text { of those who } \\
\text { received high doses were hypertensive. } \\
\text { Heart disease was found in } 17.9 \% \text { of } \\
\text { patients who received high doses of } \\
\text { chloroquine and none in the other } \\
\text { group. The QTc interval corrected by } \\
\text { the Fridericia method (QTcF) greater } \\
\text { than } 500 \text { milliseconds was mostly found } \\
\text { in the group that received high doses of } \\
\text { chloroquine and } 1 \text { patient per group } \\
\text { had myocarditis. }\end{array}$ \\
\hline $\begin{array}{c}\text { 7. Gao et al., } 2020 \\
\text { [16] } \\
\text { Respiratory Research }\end{array}$ & China & $\begin{array}{l}\text { Prognostic value of } \\
\text { NT-proBNP in } \\
\text { patients with severe } \\
\text { COVID-19. }\end{array}$ & $\begin{array}{c}54 / 24 \\
\text { male }\end{array}$ & 60.4 years & $\begin{array}{l}\text { Plasma NT-proBNP was positively } \\
\text { correlated with age, urea, cardiac injury } \\
\text { markers, and inflammation markers. } \\
\text { NT-proBNP may be an independent risk } \\
\text { factor for in-hospital death in critically } \\
\text { ill patients with COVID-19. But also a } \\
\text { history of hypertension (HP), myoglobin } \\
\text { (MYO), creatine kinase-MB (CK-MB), } \\
\text { and high-sensitivity troponin-I (Hs-TnI) } \\
\text { were correlated with the risk of in- } \\
\text { hospital death. }\end{array}$ \\
\hline
\end{tabular}

\begin{abstract}
Hypertension and coronary heart disease were found in $48 \%$ and $24 \%$ of non-survivors and $23 \%$ and $1 \%$ of survivors, respectively. Cardiac failure and acute cardiac injury occurred in $52 \%$ and $59 \%$ of non-survivors and $12 \%$ and $1 \%$ of survivors, respectively. $70 \%$ of those who died had septic shock and this did not occur in any survivors.
\end{abstract}

\begin{tabular}{|c|c|c|c|c|c|}
\hline $\begin{array}{c}\text { 9. Wang et al., } 2020 \\
\text { [17] } \\
\text { Critical care }\end{array}$ & China & $\begin{array}{l}\text { Clinical Course and } \\
\text { Outcome of } 107 \\
\text { Patients Infected } \\
\text { With the Novel } \\
\text { Coronavirus, SARS- } \\
\text { CoV-2, Discharged }\end{array}$ & $\begin{array}{c}107 / 57 \\
\text { male }\end{array}$ & 51 years & $\begin{array}{l}\text { Hypertension and cardiovascular } \\
\text { disease were found in } 52,6 \% \text { and } 36.8 \% \\
\text { of non-survivors and } 18.2 \% \text { and } 6.8 \% \text { of } \\
\text { survivors, respectively. The acute } \\
\text { cardiac injury occurred in } 42.1 \% \text { of } \\
\text { patients who did not survive and in }\end{array}$ \\
\hline
\end{tabular}


From Two Hospitals

in Wuhan, China
$4.5 \%$ of those who survived. Age and male gender were independent risk factors for death

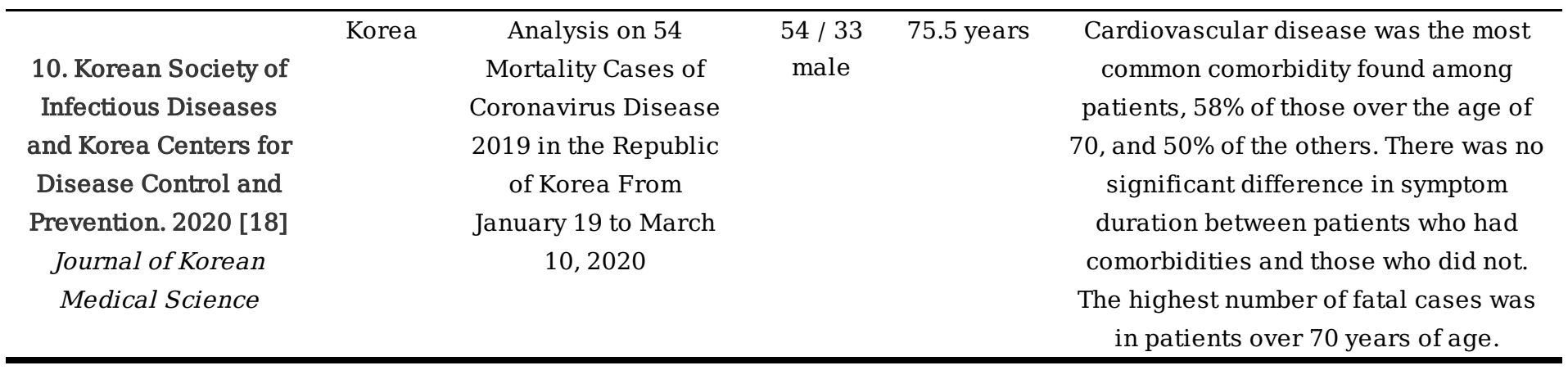

\section{Figure 1}

\section{Process of choosing the articles}

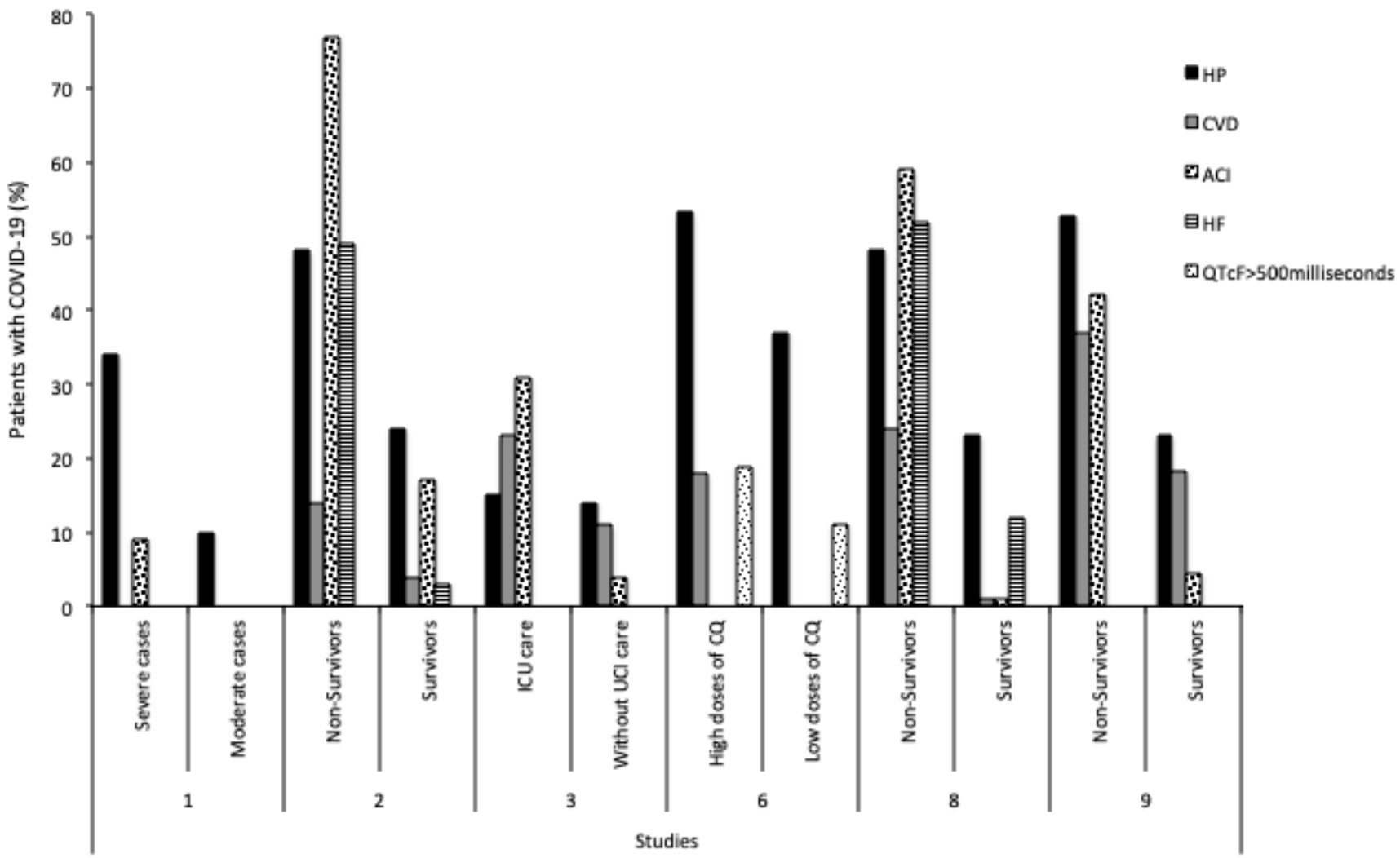

\section{Figure 2}

Comorbidities and cardiovascular complications in patients with COVID-19. The comorbidities are represented by the solid filled columns: HP - Hypertension, CVD - Cardiovascular Disease, and the complications are represented by the other columns: ACI - Acute Cardiac Injury, HF - Heart Failure, QTcF - QTc interval corrected by the Fridericia method. Moderate cases - fever and respiratory tract symptoms, etc., and pneumonia, Severe cases - any of the findings: respiratory distress, respiratory rate $\geq 30$

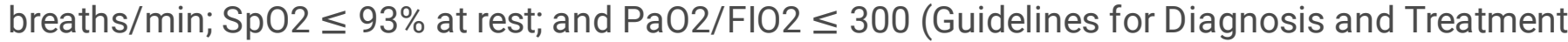


Protocol for Novel Coronavirus Pneumonia, Trial Version 7 by National Health Commission of China (http://en.nhc.gov.cn/2020-03/29/c_78469.htm) [19]. Studies (chosen out of 10 from a systematic review): 1 - Chen et al, 2020 [9] (doi: 10.1172/JCl137244), 2 - Chen et al, 2020 [10] (doi:

10.1136/bmj.m1091), 3 - Huang et al, 2020 [12] (doi: 10.1016/S0140-6736(20)30183-5), 6 - Borba et al, 2020 [15] (doi: 10.1001/jamanetworkopen.2020.8857), 8 - Zhou et al, 2020 [11] (doi: 10.1016/S01406736(20)30566-3), 9 - Wang et al 2020 [17] (doi: 10.1186/s13054-020-02895-6). 